\title{
The Use of Organic Waste as an Eco-Efficient Energy Source in Ghana
}

\author{
Robert Ohene Adu ${ }^{1}$, Reiner Lohmueller ${ }^{2}$ \\ ${ }^{1}$ Esbjerg Institute of Technology (EIT), Aalborg University, Esbjerg, Denmark; ${ }^{2}$ University of Applied Sciences, Emden, Germany. \\ Email: bertoadu@yahoo.com
}

Received February $2^{\text {nd }}, 2012$; revised March $4^{\text {th }}, 2012$; accepted April $1^{\text {st }}, 2012$

\begin{abstract}
The problem of municipal solid waste (MSW) management has been an issue of global concern in recent times and has engaged governments and local authorities in their quest to manage solid waste in a sustained manner. One proposition which has the potential of solving three problems at the same time is the use of the biodegradable component of MSW as a source of energy to augment energy supply. This research therefore assessed the use of the organic fraction of MSW as an eco-efficient energy source in Ghana. A study of Ghana's solid waste profile was undertaken and the fraction of biodegradable component was found to be approximately $60 \%$, with a heating value of $17 \mathrm{MJ} / \mathrm{kg}$ and a moisture content of $50 \%$. Moreover, it was established that $0.5 \mathrm{~kg}$ of solid waste is generated daily by each Ghanaian, meaning that about 5610 tons of the organic fraction could be made available every day to generate energy to the national grid. It was also established that waste disposal in Ghana is largely by way of open dumping as primary collection of waste from households in Ghana is limited to high-income communities which represent only $11 \%$ of the population, whereas secondary collection from transfer points to the disposal facilities is inefficient. With representative power output of 1.66 MWh/tonne a total of $3320 \mathrm{GWh}$ of energy can be produced annually from the 4 proposed plants, generating net revenue of about $\$ 111,600,000$. As an optimizing step, a waste incineration scheme was suggested in which the off-gases produced from organic waste combustion could be used to produce electrical power with steam in a multi-stage heat exchanger-steam turbine configuration, and the off gases again used for pre-drying of the organic waste in a cycle. A state-of-the art waste incineration technology was used as a model and adapted to suit Ghana's tropical conditions. MSW combustion releases less $\mathrm{CO}_{2}$ for the same power output $(837 \mathrm{Ib} / \mathrm{MWh})$ than any of the other conventional fuels do, and is therefore a good fuel for the fight against climate change.
\end{abstract}

Keywords: Municipal Solid Waste; Organic Waste; Biodegradable; Eco-Efficient; Pre-Drying; Waste Incineration; Climate Change

\section{Introduction}

As the world economy grows, so does the amount of waste generated. There is thus an increasing burden on governments and municipal authorities to find new ways of handling solid waste in an efficient and cost-effective manner.

Thermal treatment of domestic waste with energy recovery is already a popular technology in many advanced countries and is fast catching up in some developing countries today. About 35 countries worldwide currently employ Waste-to-Energy (WtE) technologies using about 130 million tons of waste annually, and this benefits some 2.6 billion people [1]. In the U.S alone, the amount of waste converted into energy is about 30 million tons a year and this produces about $2800 \mathrm{MW}$ of power.

Over the past 100 years, countries in Europe such as
Denmark and Sweden have utilized waste for electricity and district heating, with Denmark deriving $4.8 \%$ of her energy from this technology $[2,3]$. Waste-to-energy technology has particularly benefited countries with small land size such as Japan since it has been known to reduce original volumes by up to $90 \%$ and weights to as high as $67 \%$ [4].

In developing countries like Ghana where solid waste disposal is increasingly an environmental burden with its attendant health hazards, the idea of converting the organic fraction of municipal solid waste into energy for the national grid is a welcome proposition towards reducing volumes of domestic waste to be disposed of or land-filled. In addition, the conversion of organic waste into energy would doubtless cut down on the amount of fossil-derived fuel needed for the generation of power in Ghana. This will reduce the amount of $\mathrm{CO}_{2}$ emissions 
and of other noxious gases that are produced from fossilfired power plants.

At an annual growth rate of $3 \%$, Ghana's population has been estimated to double every 26 years, rising from a figure of about 6 million at independence in 1957 to an estimated 23 million in 2007 [5]. Thus, the population reached about 24 million by 2009 . This trend, coupled with a growing GDP means that the amount of municipal solid waste (MSW) generated is obviously on the increase.

Studies undertaken by [6] suggest, based on an estimated population at the time of 18 million that about 3.0 million tons (2.7 million tonnes) of solid waste were generated annually in Ghana, and that on average, each person generated daily $0.45 \mathrm{~kg}$ of solid waste. More recent data suggest that every Ghanaian generates $0.50 \mathrm{~kg}$ of solid waste daily [7]. Thus, the per-capita generation of waste in Ghana amounts to some $183 \mathrm{~kg}$ per year. This is lower than values in advanced countries which range between $250 \mathrm{~kg}$ and $750 \mathrm{~kg}$ per capita [8]. Most of these wastes find themselves in open dumps and water bodies creating nuisance in the environment, therefore any attempt to convert them into energy is a laudable idea. This paper therefore looked at the possibility of using the organic waste fraction to produce energy in Ghana by employing the Bremerhaven waste incineration plant model being used in Germany.

\section{Viability of Waste Incineration in Ghana}

\subsection{Assessment of the Heating Value of Organic Waste in Ghana}

The heating value or energy density of municipal solid waste is very much dependent on the moisture content of the waste. High moisture content in the waste considerably lowers its heating value. Thus, a distinction ought to be made between the minimum heating value of MSW which contains water and the maximum heating value of MSW which is dry.

Unlike conventional fuels which have negligible water content and therefore have practically one heating value, municipal solid wastes have high water content and therefore big differences between the minimum and maximum heating values. This means that initial energy input is required to raise the temperature of the waste to the boiling point of water and also to vaporize the water. This effectively reduces the net energy output obtainable from the combustion of MSW.

Studies undertaken by [9], to evaluate the energy potential of MSW from three zones of Accra Metropolis, the capital of Ghana, found the average moisture content to be approximately $50 \%$ (Table 1 ).

It can be seen that the mean gross calorific value of
Table 1. Mean Energy densities of MSW components from urban waste zones in Accra, Ghana.

\begin{tabular}{cc}
\hline Component & $\begin{array}{c}\text { Energy Content } \\
\text { (MJ/dry·kg) }\end{array}$ \\
\hline Organic/Putrescible & 16.84 \\
Paper and cardboard & 17.78 \\
Textile & 16.68 \\
Equal \% by weight & 15.58 \\
Plastics and rubber & $\mathrm{n} / \mathrm{a}$ \\
Mean gross energy & 16.85 \\
Moisture content & $50.00 \%$ \\
\hline
\end{tabular}

Source: Adapted from [9].

MSW in Ghana is approximately $17 \mathrm{MJ} / \mathrm{kg}$ and is largely dominated by the organic/putrescible component which constitutes about $60 \%$ of the average waste stream.

In spite of the perceived low heating values of biodegradable waste, the increasing volumes of MSW as well as the generally high percentage of the organic component observed in Ghana's MSW means that the amount of energy that can be obtained from the waste is not insignificant.

\subsection{Case Study of Bremerhaven Waste Incineration Plant}

An analysis of the waste incineration plant, BEG, in Bremerhaven, Germany is used as a case study for the proposed waste-to-energy plants for Ghana. This wasteto-energy facility was constructed in 1977 with three incineration units. Construction of a fourth unit began in 2002 and was to be completed in 2009. This fourth unit is specially designed to run on pure oxygen, as a way of reducing nitrogen oxides. The throughput of waste incinerated in this plant is 1000 tons/day.

A schematic of the various stages of the waste incineration process is given in Figures 1 and 2.

\subsection{Flow Sheet}

Figure 3 shows a flow sheet of the waste incineration process using organic waste as the main fuel. It must be borne in mind that even with organic waste combustion the scheme has all the features and elements of a massburn incineration plant. The organic waste material in Ghana still contains traces of substances that can release harmful emissions. For example, food waste is a significant source of hydrogen chloride gas since it contains chlorides from salts. However, the flue gas cleaning technology needed here is the basic technology and not the advanced technology. The metals in the ash can be recovered after incineration. 


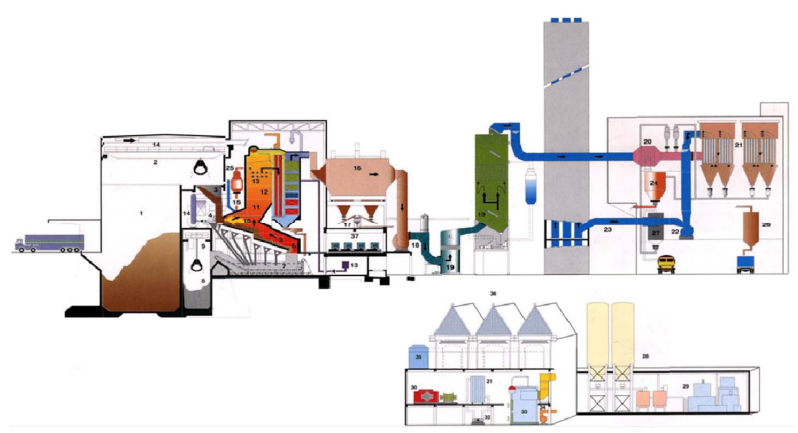

Figure 1. Schematic overview of WtE plant, BEG, Bremerhaven (http://www.beg-bhv.de/mhkw/schema.html).

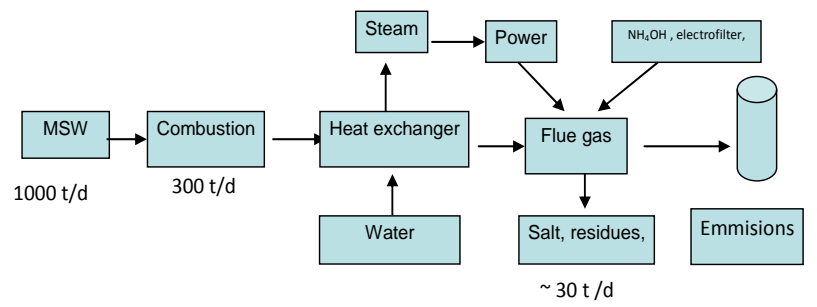

Figure 2. Materials flow diagram of waste incineration process, BEG, Germany.

\section{Results and Discussions}

\subsection{Mass and Energy Balances}

Table 2 gives an idea of the material in- and out-flows for each proposed waste-to-energy plant processing about 500,000 tonnes of waste per year. It can be deduced that a mass reduction in the waste of not less than $70 \%$ is achieved $(72.4 \%)$. The sum of the material outputs per year $(141,288.00$ tonnes/year) is much less than the total material input per year $(930,657.60$ tonnes/year) as the carbon content in the waste, together with much of the oxygen used, escape as $\mathrm{CO}_{2}$ into the atmosphere.

The proposed waste-to-energy plants are designed solely for power production. The efficiency of power production calculated here, $34.3 \%$ (Table 3) may seem low by European and global standards but comparatively high by tropical standards.

\subsection{Economic Evaluation}

\section{Capital and Operating Costs of Waste-to-Energy (WtE) Plants in Ghana}

Using a conservative estimate of annual waste generation in Ghana of 4 million tonnes per annum, for a population of 22 million, an economic evaluation is made for the construction, operation and maintenance of a waste incineration plant in Ghana serving as a waste-to-energy facility. This includes the investment or capital costs of construction as well as the running costs of the plant.

This waste-to-energy facility is suggested to run on the organic fraction of Ghana's municipal solid waste, which is approximately $60 \%$ of the waste stream. Therefore, estimate of organic waste material to be used amounts to approximately 2.4 million tonnes per annum. Assuming an availability rate of $85 \%$ for the waste material, equivalent to 313 days per annum or 7500 hours per annum, the total plant capacity in terms of tonnage of organic waste required per day is about 5610 tonnes/day.

Reference [10], on MSW incineration stipulates that a waste-to energy plant must have at least two incineration lines, and that the minimum processing capacity of each incineration line should be 240 tonnes/day $(10 \mathrm{t} / \mathrm{h})$ and its maximum capacity should be 720 tonnes/day $(30 \mathrm{t} / \mathrm{h})$. This means that, on the basis of the maximum permitted capacity, at least 8 incineration lines are required for construction in Ghana. Thus, one plant with at least 8

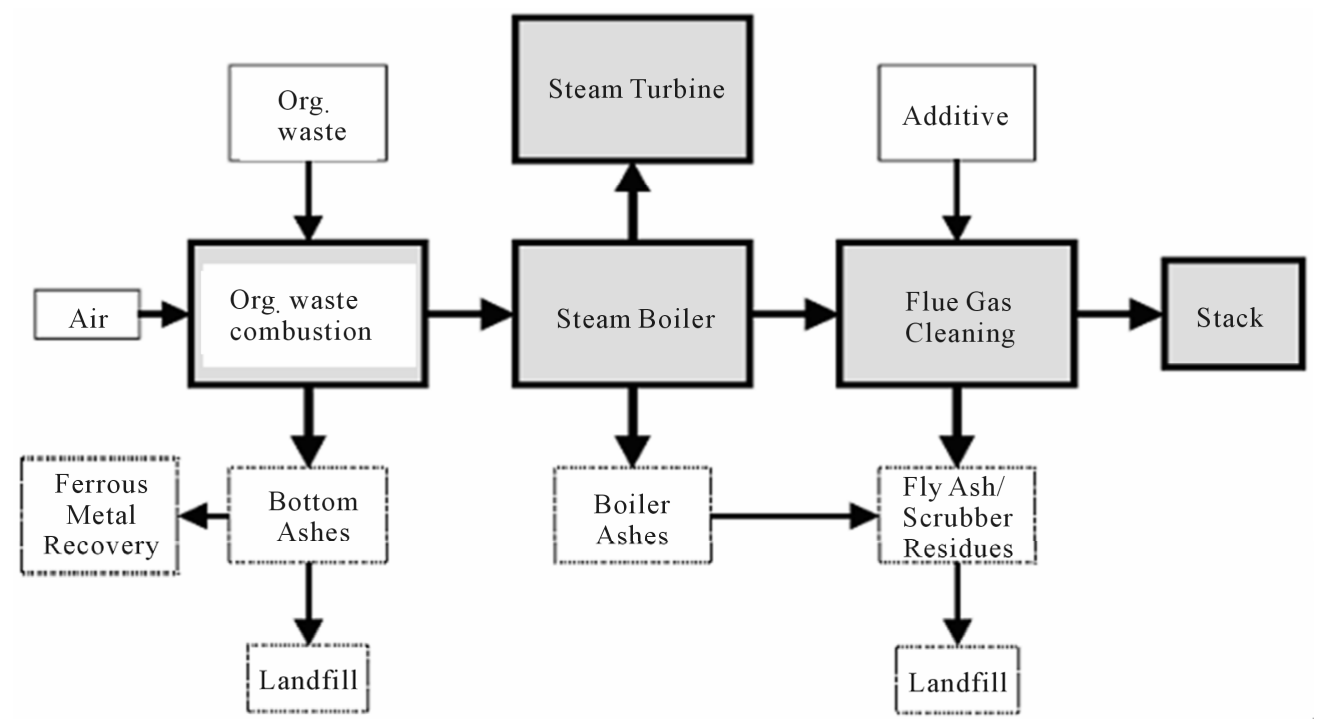

Figure 3. Process flow diagram of incineration using mainly organic waste as fuel. 
Table 2. Mass balance of proposed waste to energy plant.

\begin{tabular}{ccc}
\hline $\begin{array}{c}\text { Inputs required for } \\
\text { MSW with GCV = 16 } \\
\text { MJ/kg }\end{array}$ & $\begin{array}{c}\text { kg/tonne } \\
\text { MSW }\end{array}$ & $\begin{array}{c}\text { Material throughput } \\
\text { (kg/tonne MSW } \times \text { 511,913 } \\
\text { tonnes MSW/year) }\end{array}$ \\
\hline Oxygen & 790 & $404,410.9$ \\
Limestone & 4 & 2047.7 \\
Fuel oil & 5 & 2559.6 \\
Additives \\
$\begin{array}{c}\text { Gas cleaning) } \\
\text { Graphit/activated } \\
\text { carbon }\end{array}$ & 6 & 2559.6 \\
Sand & 4 & 2047.7 \\
Total input & 10 & 5119.1 \\
Recyclable outputs & & $\mathbf{9 3 0 , 6 5 7 . 6}$ \\
Slag & 205 & $104,942.2$ \\
Copper/iron alloy & 6 & 2559.6 \\
Residues to landfill & & $\mathbf{1 4 1 , 2 8 8}$ \\
Heavy metal sludge & 18 & 9214.4 \\
Other solid residues & 48 & \\
Total output & & $24,571.8$ \\
\hline
\end{tabular}

Table 3. Energy balance of proposed waste to energy plant.

\begin{tabular}{ccccc}
\hline \multicolumn{5}{c}{ Energy input } \\
\hline MJ/day & GJ/day & GJ/h & MJ/h & MW \\
$23,842,500$ & $23,842.5$ & 993.44 & $99,3437.5$ & 275.95 \\
& Energy output (Useful power) & \\
MWh/year & Hours/yr & MW & Efficiency/\% \\
830,000 & 8760 & 94.75 & 34.33 \\
\hline
\end{tabular}

lines or 4 plants each with at least 2 lines are required for Ghana.

The relevant costs of such a project can be divided into two broad categories, namely Capital or investment costs; and Operational and maintenance costs.

Investment costs are evaluated over a certain period of time, during which period the costs of the contract are expected to be recovered. For this research work, the investment period chosen for Ghana is 15 years. This period of time is not the duration of construction of the plant but rather the estimated lifetime of the plant.

Some of the assumptions made in order to evaluate net unit costs of organic waste treatment by incineration are:

- The investment period for recovery of capital is 15 years;

- The proposed incineration plants are designed to produce only power;

- The average heating value of Ghana's organic waste fraction is $17 \mathrm{MJ} / \mathrm{kg}$;

- Available annual organic waste supply for each of the 4 incineration plants proposed is approximately 500,000 tonnes annum (511,912.5 t.p.a);

- Prevailing interest rate in Ghana is assumed to be $6 \%$;

- Conservative estimate of electricity tariff in Ghana is 0.07 US \$/KWh (\$70/MWh);

- Annual cost of electricity, lime, water and chemicals together amount to 2 million US \$/year;

- Annual cost of administration and salaries is U.S \$3.0 million;

- Annual maintenance costs ( machinery and civil) is US \$3.0 million;

- Annual cost of Air Pollution Control (APC) residue disposal is US $\$ 100 /$ tonne;

- Annual cost of disposal/re-use of bottom ash is U.S \$5/tonne.

These estimates agree with other estimates made for future incineration plants in Britain which compare their capital and operating costs at different scales of operation.

Figure 4 shows the investment costs for a typical new waste incineration plant as a function of capacity (annual and daily). Economies of scale suggest that it is much more cost-effective to build a few, large-scale incineration plants than to build several smaller plants doing the same thing on smaller scales.

From Figure 4 it is clear that even though the investment costs of machinery and equipment as well as building engineering costs increase with increasing capacity requirement, the overall investment cost per unit capacity for larger-scale plants decreases. The investment cost for each of the four plants of capacity 500,000 tonnes of organic waste per year will be approximately $\$ 200$ million (Figure 4), whilst the total annual cost of incineration for each plant will be $\$ 30$ - \$32 million (Figure 5).

Figure 5 shows the typical relationship between the different annual costs of a waste-to-energy plant and the tonnage capacity of the plant. These annual costs include annual capital costs of depreciation due to interest rates (capitalised interest), as well as annual operating and maintenance costs. From the chart, it is also seen that even though the total annual costs - capital, and operating and maintenance-increase with increasing plant tonnage capacity, the total costs per metric tonne of waste per year goes down.

In the long term, therefore, waste-to-energy plants built for large-scale applications have a greater economic advantage than small-scale plants.

Table 4 gives representative energy and income values per tonne of incinerated waste for plants producing only power which is the focus of this work. 


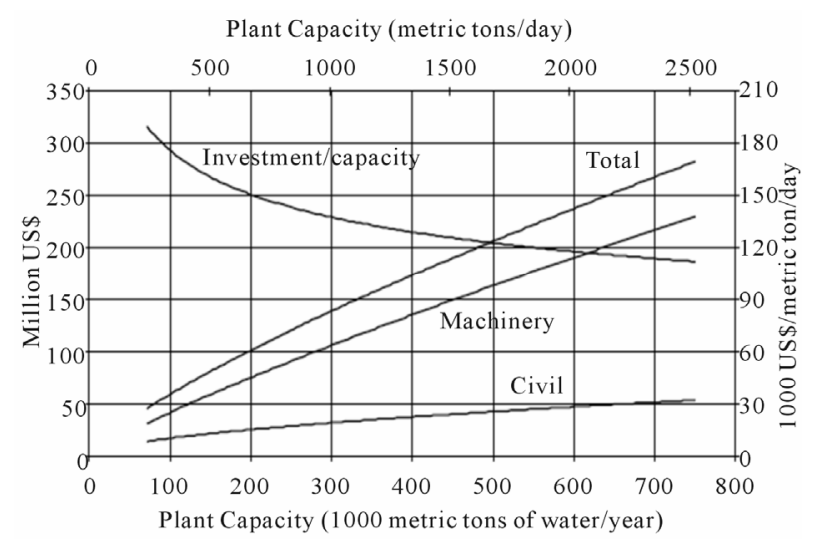

Figure 4. Investment costs of $\mathrm{WtE}$ plant as a function of capacity.

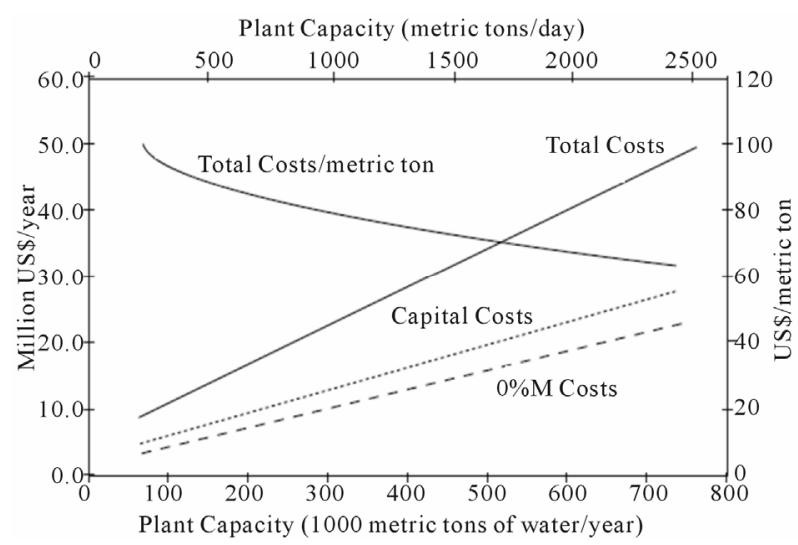

Figure 5. Annual costs of waste to energy as a function of capacity.

Table 4. Representative energy and income values per tonne of incinerated waste.

\begin{tabular}{ccc}
\hline Heat value MJ/kg & Power MWh/t & Income US\$/t \\
\hline 6 & 0.58 & 20 \\
7 & 0.68 & 24 \\
8 & 0.78 & 27 \\
9 & 0.88 & 31 \\
10 & 0.97 & 34 \\
$\mathbf{1 7}$ & $\mathbf{1 . 6 6}$ & $\mathbf{5 8 . 7}$ \\
\hline
\end{tabular}

Adapted from [10].

From this representative data set, two functions are deduced between heating value of the waste and power production on the one hand, and heating value and income generation on the other hand. With the aid of these functions (Figures 6 and 7), the amounts of power and income per tonne obtainable for Ghana's organic waste with an average heating value of $17 \mathrm{MJ} / \mathrm{kg}$ are extrapolated.

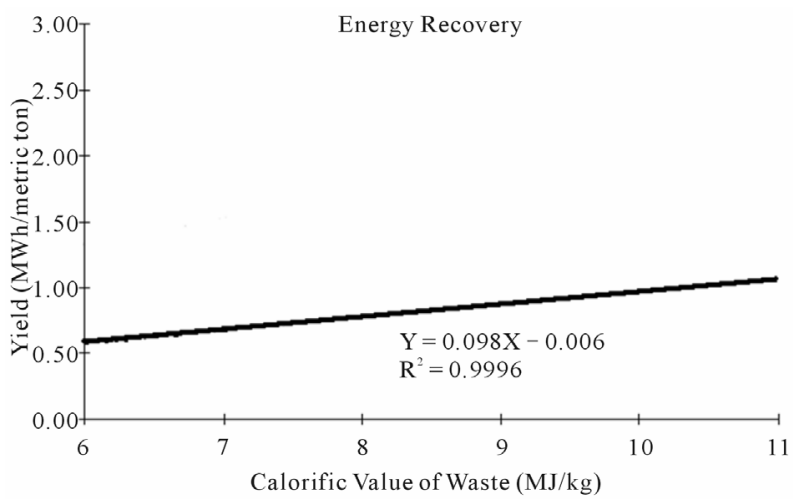

Figure 6. Correlation between energy output/tonne of incinerated waste and calorific value.

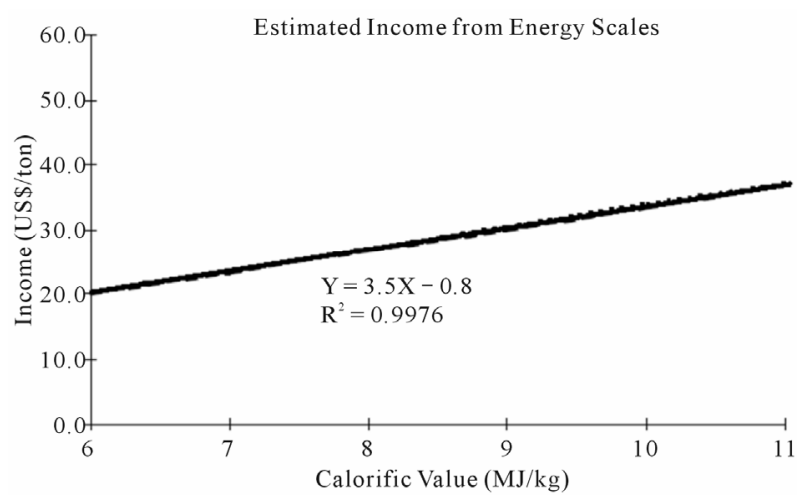

Figure 7. Correlation between income/tonne of incinerated waste and calorific value.

Thus, from Figures 6 and 7, the power output and income per tonne obtainable from incinerating the organic fraction of Ghana's MSW are 1.66 MWh/tonne and 58.7 US\$/tonne respectively.

Table 5 gives the calculation of the net treatment cost for each proposed plant on the basis of the assumptions made.

For a processing capacity of 500,000 tonnes per annum for each plant, the amount of bottom ash it will produce is estimated at 125,000 tonnes/year. This estimation is done based on the example given by [10] which estimates 75,000 tonnes/year of bottom ash for a waste processing capacity of 300,000 tonnes/year. Similarly, an amount of 15,750 tonnes/year of basic air pollution control residue is estimated to be produced from processing 500,000 tonnes of organic waste. This amount factors in a $10 \%$ reduction in Air Pollution Control (APC) residue amount and costs due to basic level emission control technology to be used in the design. The organic fraction in MSW has less polluting substances than the mixed waste stream.

From Table $\mathbf{5}$ it is seen that there is clearly an annual net benefit of $\$ 27.9$ million from each incineration plant processing 500,000 tonnes of organic waste annually, or 
Table 5. Calculation of net treatment cost or benefit for each plant.

\begin{tabular}{|c|c|c|c|}
\hline $\begin{array}{l}\text { Processing } \\
\text { capacity }\end{array}$ & 500,000 tons p.a & $\sim 1400 \mathrm{t} / \mathrm{d}$ & $\sim 58 \mathrm{t} / \mathrm{h}$ \\
\hline \multicolumn{4}{|c|}{ Output } \\
\hline Bottom ash & $125,000 \mathrm{t} / \mathrm{y}$ & & \\
\hline APC residues & $15,750 \mathrm{t} / \mathrm{y}$ & & \\
\hline Electricity for sale & $\begin{array}{c}830,000 \\
\text { MWh/year }\end{array}$ & & \\
\hline Investment & & $\begin{array}{l}\$ 200.0 \\
\text { million }\end{array}$ & Cost/tonne \\
\hline $\begin{array}{l}\text { Annual capital } \\
\text { cost (6\% p.a, } \\
15 \text { years) }\end{array}$ & & $\begin{array}{l}\sim \$ 20.0 \\
\text { million }\end{array}$ & \$40/tonne \\
\hline \multicolumn{4}{|c|}{ Annual operating costs } \\
\hline $\begin{array}{l}\text { Administration/ } \\
\text { salaries }\end{array}$ & $\$ 3.0$ million & & \\
\hline $\begin{array}{l}\text { Electricity, lime, } \\
\text { water, chemicals }\end{array}$ & $\$ 2.0$ million & & \\
\hline $\begin{array}{c}\text { APC residue } \\
\text { disposal } \\
\text { (at } \$ 100 / \text { tonne) }\end{array}$ & $\$ 1.575$ million & & \\
\hline $\begin{array}{l}\text { Disposal/re-use of } \\
\text { bottom ash } \\
\text { (\$5/tonne })\end{array}$ & $\$ 0.625$ million & & \\
\hline $\begin{array}{l}\text { Maintenance } \\
\text { (machinery } \\
\text { and civil) }\end{array}$ & $\$ 3.0$ million & & \\
\hline $\begin{array}{c}\text { Total operating } \\
\text { cost }\end{array}$ & $\$ 10.2$ million & $\begin{array}{c}\$ 10.2 \\
\text { million }\end{array}$ & \$20.4/tonne \\
\hline $\begin{array}{l}\text { Total annual } \\
\text { costs }\end{array}$ & & $\begin{array}{l}\$ 30.2 \\
\text { million }\end{array}$ & \$60.4/tonne \\
\hline $\begin{array}{l}\text { Annual revenue } \\
\text { from energy sale } \\
\text { (at } \$ 70 / \mathrm{MWh})\end{array}$ & & $\begin{array}{l}\$ 58.1 \\
\text { million }\end{array}$ & \$116.2/tonne \\
\hline Annual net benefit & & $\begin{array}{c}\$ 27.9 \\
\text { million }\end{array}$ & \$55.8/tonne \\
\hline
\end{tabular}

$\$ 55.8$ for every tonne of organic waste incinerated in each plant. Thus, the investment cost of $\$ 200$ million made on each incineration plant can be recovered in seven years, which is halfway down the investment period of 15 years.

Depending on the prevailing electricity tariff, location of the plants and the transport costs of the waste for that matter, this benefit may be reduced or increased by varying percentages.

\subsection{Location of Proposed Waste-to-Energy Plants in Ghana}

Depending on the demand of the local energy market, an MSW incineration plant will generate surplus energy, which may be made available in the form of heat or power. Such a plant in Ghana must be designed solely for power production since there is no demand for warm water in Ghana at the moment. In that respect, an MSW plant is comparable to a fossil fuel power plant. It is further comparable to a coal-fueled power plant with respect to flue gas emissions and solid residues from the combustion process and flue gas cleaning. Therefore, a waste incineration plant should be close to an existing fossil fuel power plant for the two plants to enjoy mutual benefits from the service facilities needed - or it could be adjacent to or part of a new power plant [10].

Furthermore, the design and operation of a modern waste incineration plant in Ghana must have an adequate and cheap supply of water for cooling and for scrubbing of the flue gas to be produced. Therefore, locating one or two of these plants close to the sea will ensure a ready supply of water for cooling and for the washing process. On the west coast of Ghana, there is an existing thermal power plant, the Aboadze Thermal Power Plant, with a combined cycle generating capacity of $650 \mathrm{MW}$ which runs on light crude oil and distillate fuel oil. The plant has dual firing capacity and is being converted to run on natural gas. It is proposed that a waste-to-energy plant running on organic waste is sited close to this thermal power facility.

Most of the industries in Ghana are situated in the southern part, along the coast, and this is where urbanisation and the solid waste problem in Ghana are concentrated.

\subsection{Emissions Analyses}

\subsubsection{Carbon Emissions Analysis}

The organic fraction of MSW can be regarded as renewable energy, since it is of biological origin. Plants absorb carbon dioxide $\left(\mathrm{CO}_{2}\right)$ from the atmosphere and form this organic product. The biodegradable fraction in MSW has therefore the same mass fraction of carbon as has $\mathrm{CO}_{2}$ itself $(27 \%)$. Burning the organic fraction releases the same amount of $\mathrm{CO}_{2}$ into the atmosphere as the amount of $\mathrm{CO}_{2}$ used in its production, and therefore will not contribute any more $\mathrm{CO}_{2}$ into the atmosphere.

The bio-fraction of MSW is formed from plants usually within the last growing season, although some will have accumulated over longer periods e.g. wood and wood products such as paper. If it is burned, the $\mathrm{CO}_{2}$ produced can be fixed in one growing season by regrowing the plants used in their production.

In the combustion of organic waste, all the carbon content is emitted as $\mathrm{CO}_{2}$ to the atmosphere. Thus, combustion of 1 tonne of dry organic waste will produce approximately 1 tonne of $\mathrm{CO}_{2}$. In contrast, 1 tonne of organic waste land-filled will produce about 5.2 tonnes of $\mathrm{CO}_{2}$ - equivalent [11]. In deducing this equivalent amount 
of $\mathrm{CO}_{2}$, the following assumptions were made: that $25 \%$ of land-filled MSW is biodegradable, landfill gas generally contains $54 \%$ methane and $46 \%$ carbon dioxide, The maximum capacity of land-filled MSW to produce methane is 62 standard $\mathrm{m}^{3}$ of $\mathrm{CH}_{4} /$ tonne of MSW [12], An amount of 109 million tonnes MSW was deposited in US landfills as of 1999. The annual capture of landfill gas in the US is 8 billion $\mathrm{Nm}^{3}$ [13], the first IPCC assessment in 2001 put the global warming potential of methane as 23 times more than that of $\mathrm{CO}_{2}$ [14], the density of methane (at $1.013 \mathrm{bar}$ and $15^{\circ} \mathrm{C}\left(59^{\circ} \mathrm{F}\right)$ ) is 0.68 $\mathrm{kg} / \mathrm{m}^{3}$.

Amount of non-captured Methane

$=$ Amount generated - Amount captured

$=\left(109\right.$ million tonnes MSW $\times 62 \mathrm{Nm}^{3} /$ tonne $)-(8$ billion $\left.\mathrm{Nm}^{3} \times 0.54\right)$

$=2.4$ billion $\mathrm{Nm}^{3}$ of methane

$=1.7$ million tonnes of methane $(\mathrm{vol} \times$ density $)$

$=39.1$ million tonnes of carbon equivalent

$=0.369$ tonnes of carbon equivalent/tonne MSW

$=1.32$ tonnes of $\mathrm{CO}_{2} /$ tonne MSW

$=5.28$ tonnes of $\mathrm{CO}_{2} /$ tonne biodegradable waste

A study [1], on MSW generation in New York State revealed that if every tonne of MSW land-filled were instead to be combusted, it would save a barrel of crude oil and therefore reduce greenhouse gas emissions by 1.1875 tonnes.

\subsubsection{Comparison of Emissions}

A study undertaken by [15] to compare emissions of carbon dioxide $\left(\mathrm{CO}_{2}\right)$, sulphur dioxide $\left(\mathrm{SO}_{2}\right)$ and nitrogen dioxide $\left(\mathrm{NO}_{2}\right)$, from $\mathrm{MSW}$, coal, oil and natural gas found that waste-fired power plants emitted significantly less $\mathrm{CO}_{2}(837 \mathrm{Ib} / \mathrm{MWh})$ than any of the other fossil fuel power plants. The results also show that waste-fired plants emitted less $\mathrm{SO}_{2}(0.8 \mathrm{Ib} / \mathrm{MWh})$ than coal- and oil-fired plants and less $\mathrm{NO}_{2}$ than coal power plants (Table 6). It however emitted more $\mathrm{SO}_{2}$ than natural gas and more $\mathrm{NO}_{2}$ than oil and natural gas.

The relatively high emissions of $\mathrm{NO}_{2}$ and $\mathrm{SO}_{2}$ from MSW (compared with N.G) could be reduced by isolating

Table 6. Amounts of $\mathrm{CO}_{2}, \mathrm{SO}_{2}$, and $\mathrm{NO}_{2}$ from the various fuels for the same energy.

\begin{tabular}{cccc}
\hline \multirow{2}{*}{ Fuel } & $\mathbf{C O}_{2}$ & $\mathbf{S O}_{2}$ & $\mathbf{N O}_{2}$ \\
\cline { 2 - 4 } & \multicolumn{2}{c}{ Pounds per Megawatt-Hour (Ib/MWh) } \\
\hline MSW & 837 & 0.8 & 5.4 \\
Coal & 2249 & 13 & 6 \\
Oil & 1672 & 12 & 4 \\
Natural gas (N.G) & 1135 & 0.1 & 1.7 \\
\hline
\end{tabular}

Source: [15]. the organic fraction for use in the waste-to-energy conversion.

\subsubsection{Dioxin Emissions}

Before the 1990s, existing incinerators in Europe and U.S were significant sources of dioxin emissions. Strict legislation has however reduced its levels. In the US for example, dioxin emissions decreased from 14,000 grams of toxic equivalent (TEQ) in 1987 to $1400 \mathrm{~g}$ in 2000 [16]. In Germany, dioxin emissions from known sources have dropped by more than 90 percent between 1990 and 2004 [17].

Incineration plants have been found to emit less dioxin than household burning of wastes, and that, chimneys and tiled stoves in private households alone discharge approximately 20 times more dioxin into the environment than incineration plants.

\subsubsection{Other Emissions}

In terms of the other emissions, figures extracted from [18] assessing the amounts of carbon monoxide (CO), hydrochloric acid gas $(\mathrm{HCl})$, particulates $(\mathrm{PM})$ and hydrocarbons (HC) emitted for the same energy produced are shown in Table 7.

It can be seen that municipal solid wastes emit less carbon monoxide, less particulates and less hydrocarbons than all the other conventional fuels shown. The only exception is HCL emission for which MSWs exceed oil and natural gas, and this is due to the presence of chlorides found in the waste stream from items such as table salt and polyvinyl chlorides.

\subsection{Further Steps in Optimization}

\section{Efficiency Improvement by Integrating Heating of Liquid Methane}

Most incineration facilities in Europe and other temperate climates use the considerable amounts of waste heat generated to heat water in district heating schemes. In tropical countries like Ghana where there is no demand for warm water, this may not be necessary. The waste heat associated with the steam turbine process can instead be

Table 7. Emissions of CO, HCl, PM, and HC in Ib/MWh.

\begin{tabular}{ccccc}
\hline \multirow{2}{*}{ Fuel } & CO & HCl & $\begin{array}{c}\text { Particulates } \\
\text { (PM) }\end{array}$ & $\begin{array}{c}\text { Hydro } \\
\text { carbons }\end{array}$ \\
\cline { 2 - 5 } & \multicolumn{3}{c}{ Pounds per Megawatt-Hour (Ib/MWh) } \\
\hline MSW & 0.36 & $\sim 2.2$ & $\sim 0.25$ & $\sim 0.02$ \\
Coal & 0.65 & $\sim 12$ & $\sim 1.7$ & $\sim 0.18$ \\
Oil (No. 6) & 0.40 & - & $\sim 0.5$ & $\sim 0.08$ \\
$\begin{array}{c}\text { Natural gas } \\
\text { (N.G) }\end{array}$ & 0.40 & $\sim 0.9$ & $\sim 1.25$ & $\sim 0.03$ \\
\hline
\end{tabular}

Adapted from [18]. 
used to first dry the organic waste in a closed cycle, to raise its heating value, before it is burned to produce energy. The steam turbine process has an efficiency of $45 \%$. Thus, only $45 \%$ of the energy obtainable from fuel combustion is available for electricity. The rest of the energy $(55 \%)$ is heat at a low temperature.

Thus, a combined cycle plant can be designed that uses the hot flue gases produced from organic waste combustion to generate steam and gasify liquid methane in stages to turn a steam turbine and a gas turbine respec- tively [19], and the flue gases, cooled down, can be used to pre-dry the organic waste in a cycle for use as fuel to increase the efficiency of the plant.

Figure 8 gives an example of a waste-fired power plant working as a combined cycle power plant with a two-stage turbine process using aqueous ammonia (Ammonia-water) and liquid methane (LNG) as the working fluids. This design can be modified to add pre-drying of the waste using the off-gases produced from combustion of the organic waste (Figure 9). The off-gases, at nearly

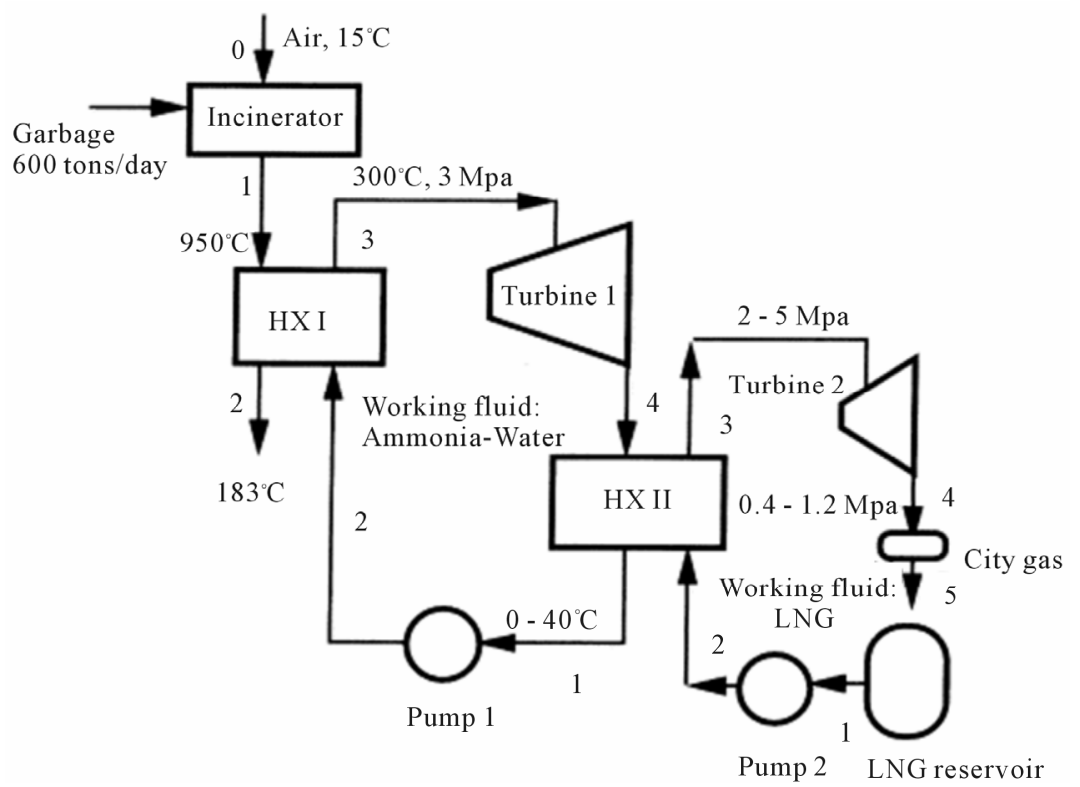

Figure 8. Combined power cycle using garbage incineration and LNG cold energy [19].

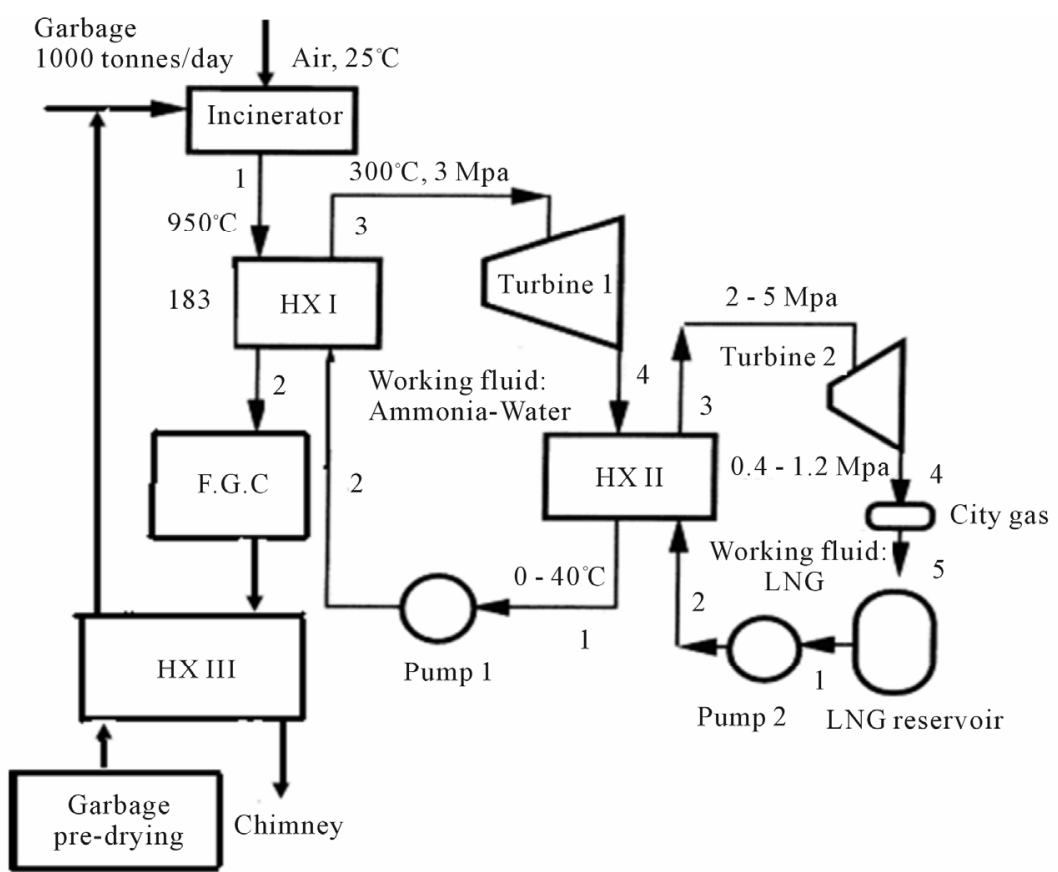

Figure 9. Design of combined cycle waste incineration plant with optimizing steps. 
$1000^{\circ} \mathrm{C}$, heat up and vaporize the aqueous ammonia by means of a heat exchanger (HX 1), and the steam produced at 30 bars and $300^{\circ} \mathrm{C}$ turns a steam turbine for electrical power generation. Additional power generation is obtained when the expanded steam at a lower temperature $\left(0^{\circ} \mathrm{C}-40^{\circ} \mathrm{C}\right)$ is made to vaporize liquid methane by means of a second heat exchanger (HX 2) and the methane gas used to turn another turbine (gas turbine).

The off-gases, after heat exchange with the aqueous ammonia are still hot enough $\left(183^{\circ} \mathrm{C}\right)$ and, after scrubbing, can be used to pre-dry the incoming organic waste by means of another heat exchanger (HX 3) before it is released into the atmosphere through the stack at about $120^{\circ} \mathrm{C}$.

This optimizing step involves the use of liquid methane as the second working fluid. This is feasible in the sense that Ghana expected to get a supply of natural gas from her sister country, Nigeria, since the end of 2008. The contractual agreement has long been finalized and pipelines have been laid between the two countries. The gas can be liquefied under pressure, gasified through the heat exchanger (HX II) and used to turn a gas turbine for additional power before being sold to the public.

Natural gas, when combusted, has been identified as the most eco-friendly fuel of choice after municipal solid waste. This is because methane has relatively fewer carbon atoms per molecule than coal or oil has and, on combustion, releases less $\mathrm{CO}_{2}$ for the same energy output than coal or oil does [18]. Additionally, methane has virtually no sulphur-content and therefore performs much better in minimizing $\mathrm{SO}_{2}$ emissions than all the other fuels on combustion, and also does better in $\mathrm{NO}_{2}$ than the other fuels.

However, this is not the case when methane is flared instead of being combusted. Methane is about 23 times more potent as a greenhouse gas than $\mathrm{CO}_{2}$ [14]. The problem with land filling in Ghana is that besides limited land space, the technology to properly capture methane and use it as a combustible fuel is not there at the moment.

\section{Conclusions}

This research paper has sought to assess the use of the organic fraction of municipal solid waste for clean energy. Although it is established that municipal solid waste has a relatively low calorific value, the benefits which its direct conversion to energy will bring to Ghana's sanitation and to climate protection cannot be overemphasized.

Four waste-to-energy plants designed for the treatment of the organic fraction of MSW in Ghana are proposed. These plants will each process approximately 500,000 metric tons of organic waste annually. Economies of scale suggest that it is more cost-effective to construct a few, large-scale incineration plants than many small- scale plants doing the same thing.

Conventional incinerators processing more than 300,000 tonnes per annum of waste usually have net electrical power output of $550-600 \mathrm{kWh}$ per tonne of MSW [20]. In the case of Ghana, the 4 proposed plants, designed to produce only power from organic waste, will have a representative power output of $1660 \mathrm{KWh}$ per tonne. Therefore, the four plants, each with a processing capacity of 500,000 tonnes per annum and an output of $830 \mathrm{GWh} /$ annum, will be able to supply a combined output of 3320 GWh per annum to the national electricity grid and a combined net revenue of about $\$ 111,600,000$ per annum for Ghana.

It is established that municipal solid waste as a fuel source performs better towards greenhouse gas minimization (837 $\mathrm{Ib} \mathrm{CO}_{2} / \mathrm{MWh}$ ) than all the conventional fuels and performs better than coal in $\mathrm{SO}_{2}$ and $\mathrm{NO}_{\mathrm{X}}$ minimization. The merits of waste incineration cannot be viewed in isolation, but in comparison with other waste treatment options such as land filling. It is now known that if every ton of MSW land-filled were instead to be combusted, it would save a barrel of crude oil and therefore reduce greenhouse gas emissions by 1.1875 tons.

\section{Acknowledgements}

I gratefully acknowledge Professor, Dr-Ing Reiner Lohmueller, of the Fachhochschule Oldenburg Ostfriesland, Wilhelmshaven, FHOOW, Emden, Germany, for his supervisory guidance and technical insight in helping me write my M.Sc thesis from which this paper is developed.

I am grateful to Dr David Essumang, Senior Lecturer of University of Cape Coast, Ghana, for his fine-tuning support towards this manuscript and for recommending this journal.

\section{REFERENCES}

[1] N. J. Themelis, "Overview of Waste-to Energy Technology," Columbia University, New York, 2003.

[2] H. Kleis, et al., "100 Years of Waste Incineration in Denmark," 2004.

[3] Danish Ministry of Energy, "Danish Energy Statistics," 2005.

[4] G. H. Williams, P. J. Massey, P. Shepherd and A. Cole, "Incineration of Waste II-Module 54," De Montfort University, Leicester, 1995.

[5] World Info Zone, "Ghana Information-Page 1," 2008. www.worldinfozone.com/country.php? country=Ghana

[6] A. Mensah and E. Larbi, "Solid Waste Disposal in Ghana," 2005.

www.lboro.ac.uk/well/resources/fact-sheets/fact-sheets-ht $\mathrm{m} / \mathrm{RSA} \% 20$ Solid\%20waste.htm

[7] L., Demedeme, "Every Ghanaian Generates Half Kilogram of Solid Waste Daily_Sanitation Expert," 2008. 
www.ghananewstoday.com

[8] European Environment Agency, "Municipal Waste Generation Per Capita," 2007. www.eea.europa.eu/

[9] J. N. Fobil, D. Carboo and N. A. Armah, "Evaluation of Municipal Solid Wastes (MSW) for Utilisation in Energy Production in Developing Countries," International Journal of Environmental Technology and Management, Vol. 5, No. 1, 2005, pp. 76-86. doi:10.1504/IJETM.2005.006508

[10] The World Bank, "Municipal Solid Waste Incineration," World Bank Technical Guidance Report, 1999.

[11] N. J. Themelis, "An Overview of the Global Waste-toEnergy Industry,” 2003. www.iswa.org

[12] Franklin Associates, "The Role of Recycling in Integrated Waste Management in the United States," 1995.

[13] E. Berenyi, "Methane Recovery from Landfill Yearbook," 5th Edition, Governmental Advisory Associates, Westport, 1999.

[14] C. Kemfert and W.-P. Schill, "An Analysis of Methane Mitigation as a Response to Climate Change," 2012. http://fixtheclimate.com/uploads/tx_templavoila/AP_Met hane_Kemfert_Schill_v.5.0.pdf

[15] J. K. O'Brien, "Comparison of Air Emissions from
Waste-to-Energy Facilities to Fossil Fuel Power Plants," 2005

[16] U.S. Environmental Protection Agency, “An Inventory of Sources and Environmental Releases of Dioxin-Like Compounds in the U.S. for the Years 1987, 1995, and 2000," 2006.

[17] The German Federal Ministry for the Environment, Nature Conservation and Nuclear Safety, "EU-wide Consumer Protection Against Environmental Contaminants in Food-Dioxins and Polychlorinated Biphenyls (PCBs)," 2012.

http://www.bmu.de/english/food_safety/consumer_protec tion_eu/doc/41969.php

[18] Delaware Solid Waste Authority, "Waste to Energy Program 4," 1994.

www.dswa.com/programs_wastetoenergy4.asp

[19] T. Miyazaki, Y. T. Kang, A. Akisawa and T. Kashiwagi, "A Combined Power Cycle Using Refuse Incineration and LNG Cold Energy," Energy, Vol. 25, No. 7, 2000, pp. 639-655. doi:10.1016/S0360-5442(00)00002-5

[20] W. R. Livingstone, "Technical and Economic Assessment of Energy Conversion Technologies for MSW," 2002. www.michiganrecycles.org/pdf/British_Conversion_Tech _Report.pdf 